Sławiński, Janusz. „Myśli na temat: biografia pisarza jako jednostka procesu historyczno-literackiego”. W: Biografia, geografia, kultura literacka, red. Janusz Sławiński, Jerzy Ziomek, 9-23. (Wrocław: Zakład Narodowy im. Ossolińskich - Wydawnictwo, 1975).

Śliwińska, Monika. Wyspiański. Dopóki starczy życia. Warszawa: Iskry, 2017.

Tekcam, Rana. The Biographer and the Subject. A Study on Biographical Distance. Stuttgart: Ibidem-Verlag, 2010.

Wołowiec, Grzegorz. „O Domosławskim i jego krytykach”. Teksty Drugie 1-2 (2011): 279-287.

Ziomek, Jerzy. „Autobiografizm jako hipoteza konieczna («Treny» Jana Kochanowskiego)”. W: Biografia, geografia, kultura literacka, red. Janusz Sławiński, Jerzy Ziomek, 41-60. Wrocław: Zakład Narodowy im. Ossolińskich - Wydawnictwo, 1975.

\title{
Aleksander. A Biographical Phantasy
}

\section{Summary}

Article presents critical analysis of Bolesław Prus’s biography Prus. Śledztwo biograficzne (biographical investigation) by Monika Piątkowska. Author of the article discuss asumptions of Piątkowska's biographical method based on arbitrary recognition that fictional works by Prus are undisputable, absolutely reliable source of knowledge about his life as well as disclose biographer's attitude on what real literature is supposed to be (expressivistic theory of literary work). Demitologising biography by Piątkowska does not do justice to its subject, but attempt to meet readers desire for gossip and excess.

\section{Keywords}

biography, Bolesław Prus, demitologisation, biographical criticism

Translated by Marcin Romanowski

\section{PROSIMY O CYTOWANIE TEGO ARTYKUŁU JAKO:}

Marcin Romanowski, „Aleksander. Fantazja biograficzna”, Autobiografia. Literatura. Kultura. Media 2 (2018), 11: 115-128. DOI 10.18276/au.2018.2.11-08 


\section{Aa@}

AUTOBIOGRAFIA nr 2 (11) 2018 s. 129-141

ISSN 2353-8694

DOI: 10.18276/AU.2018.2.11-09
BIOGRAFIE

MATEUSZ SKUCHA*

Uniwersytet Jagielloński

\section{Jej ojciec. Zofia Nałkowska}

\section{Streszczenie}

Artykuł dotyczy niedokończonej książki Zofii Nałkowskiej poświęconej ojcu, Wacławowi Nałkowskiemu. Rozpoczyna się od wspomnienia jego ostatnich chwil, umieszczonych w kontekście innych podobnych wspomnień zanotowanych przez pisarki feministyczne (Nancy K. Miller, Grażynę Borkowską, Ingę Iwasiów, Ericę Jong i Susan Faludi). Następnie jest mowa o samej relacji Nałkowskiej z ojcem. Później zaś - o metodzie pracy nad książką, czego efektem był szereg artykułów. Materiały do książki o ojcu, publikowane na łamach prasy, są interesującymi tekstami ze względu na swoją przynależność gatunkową. Przede wszystkim stanowią biografię, ale też - autobiografię. Ich różnorodność zbliża je do gatunków sylwicznych, a także - do eseju.

Słowa kluczowe

Zofia Nałkowska, Wacław Nałkowski, esej, autobiografia, kobieta

Minęło wiele lat od tej nocy, gdy w małym, ciemnym pokoju szpitalnym rozstawałam się z nim na zawsze. Trzymałam jego rękę w mojej i czekałam, aż przestanie oddychać. Nie wiedział o tym, że odchodzi, nie dowiedział się nigdy. Zostało mu oszczędzone straszliwe cierpienie rozstania. Wzięłyśmy je całe na siebie, my trzy.

\footnotetext{
* Kontakt z autorem: mateusz.skucha@gmail.com
} 
Była to pierwsza rzecz, którą przed nim ukryłam, której nie mogłam mu powiedzieć. Później już znalazłam w jego pismach te słowa: „O naturo, ty niepojęta, czymkolwiek jesteś, dzięki ci, dzięki za całe życie”.

Nastały noce, w których powtarzał się sen, że ojciec żyje i ja mówię mu, jak to było, mówię o tej ostatniej nocy, o matce. I budziłam się z przerażeniem.

Wzięłyśmy na siebie to cierpienie. I ujawniła się teraz najważniejsza rzecz w żałobie - jego nieobecność. Każda rzecz życia była niedokonana, każda była niezupełna, nie doznana do końca - skoro nie można mu było o niej powiedzieć, nie można się było o nic zapytać. Wszystko już odbywało się bez niego.

Przez długie miesiące, przez całe lata stosowałam do rzeczy jego domniemany sąd. W jego pismach szukałam miar i kryteriów co z życia mam odrzucić a co przyjąć. Nie mogąc sama podjęć decyzji, robiłam to jednak z jego pomocą ${ }^{1}$.

Tymi słowami Zofia Nałkowska rozpoczyna cykl artykułów o swoim ojcu - Wacławie Nałkowskim. Jest rok 1947. Od jego śmierci minęło trzydzieści sześć lat. Kiedy umierał, Zofia miała lat dwadzieścia siedem. W chwili pisania tekstu ma sześćdziesiąt trzy. Żyje na świecie trzy lata dłużej niż Wacław. Przetrwała dwie wojny światowe. Jest pisarką i feministką.

Jednym z feministycznych priorytetów było odzyskanie kobiecej genealogii, czyli rekonstrukcja matrylinearności, powrót do matek, o czym świadczą chociażby takie książki, jak Ciało-w-ciało z matką Luce Irigaray czy Zrodzone z kobiety Adrienne Rich ${ }^{2}$. Pojawia się tu jednak pytanie o to, co zrobić z ojcem. Ale nie tym symbolicznym, patriarchalnym, abstrakcyjnym, o którym jest mowa na przykład w tomach Refiguring the Father Patrici Yeager i Elizabeth Kowaleski-Wallace (1989) czy Their Fathers' Daughters Elizabeth Kowaleski-Wallace (1991), lecz o ojcu bardzo realnym, cielesnym, namacalnym. Zwłaszcza w sytuacji jego śmierci. Jak opowiedzieć jego umieranie? Jak opowiedzieć siebie? Jak sobie poradzić?

Krytyczki feministyczne próbowały uporać się z tym na różne sposoby. W 1991 roku Nancy K. Miller wydała esej My Father's Penis - wspomnienie ostatnich chwil ojca. Tekst intymny, autobiograficzny staje się okazją do sformułowania wniosków ogólnych i teoretycznych. Autorka

przywołuje własne doświadczenie - stwierdza jedna komentatorek tego eseju - by odrzucić związane z psychoanalizą niejasne, lecz dominujące pojęcie fallusa. To nie fallus rządzi światem, lecz śmierć, prawo do jej orzekania, egzekwowania. Fantazmat ojcowskiej

1 Zofia Nałkowska, „O Wacławie Nałkowskim. Rozdział pierwszy książki o ojcu”, Odrodzenie 47 (1947): 1.

2 Zauważyć tu należy, że polskie przekłady tytułów obu książek nie do końca oddają wymowę oryginałów. Le corps-à-corps avec la mère można równie dobrze tłumaczyć jako „ciało-w-ciało przeciwko matce”. Z kolei Of Woman Born da się przełożyć zarówno jako „zrodzone”, jak i „zrodzeni”. 
siły zostaje tutaj pozbawiony swego seksualno-władczego ekwiwalentu. Ale pozostaje cień własnego zalęknienia wobec ojca i pamięci o nim³ .

W 2004 roku Grażyna Borkowska opublikowała na łamach „Tekstów Drugich” esej naukowy pod tytułem Opowiedzieć umieranie, w którym interpretuje relacje auto/biograficzne kilku pisarzy i pisarek (Dąbrowskiej, Nałkowskiej, Różewicza, Miller i Rotha) dotyczące śmierci któregoś z rodziców. I nie byłoby w tym nic nadzwyczajnego, gdyby nie dedykacja: „Mojemu Ojcu”. Analizując doświadczenia innych, badaczka próbuje „sobie poradzić”. Wobec tak przyjętej optyki zakończenie artykułu nabiera dodatkowego znaczenia: „trajektoria cierpienia poddanego narracyjnej obróbce, wysokoartystycznej, literacko doskonałej, wydaje się, mimo wszystkich wątpliwości, mniej bezładna, choć zawsze jednakowo bezbronna wobec ostatecznego" 4 .

W 2013 roku Inga Iwasiów wydaje książkę pod tytułem Umarł mi, o której Andrzej Franaszek pisał: „Dziennik żałoby, raport z rozpacz. Zapis uczuć dojrzałej kobiety, córki, która niespodziewanie traci ojca, musi przyjąć jego śmierć, nie pozwolić, by świat wokół się rozpadł. Oswoić otchłań” 5 .

W 2015 Erica Jong przygotowuje tom Fear of Dying, a w nim dwa eseje poświęcone ojcu My Father (Boy Wanted) oraz Loving Mr Bones, który rozpoczyna się tak:

Czy kiedykolwiek spędziłaś dzień biegając między jednym szpitalem a drugim? Tym właśnie stało się moje życie. Ojciec ponownie był w szpitalu. Nieustannie trafiał do niego i wychodził - jak ludzie pod koniec życia. Mój ojciec był w szpitalu Mount Sinai, mój mąż - w Szpitalu Nowojorskim, a ja byłam niby lotka kursująca między nimi, napędzana miłością i strachem ${ }^{6}$.

W 2016 roku Susan Faludi publikuje książkę W ciemni, poświęconą historii jej ojca. W finale zamieszcza następujące wyznanie:

Spoglądałam na twarz mojego ojca, odwróconą teraz ode mnie, tak samo, jak często bywała za jej życia. Przez wszystkie dane jej lata próbowała odpowiedzieć sobie na pytanie, kim jest. Żydem czy chrześcijaninem? Węgrem czy Amerykaninem? Kobietą czy mężczyzną? Tak wiele przeciwieństw. Ale teraz, patrząc na jej martwe ciało, pomyślałam:

3 Grażyna Borkowska, „Opowiedzieć umieranie”, Teksty Drugie 5 (2004): 44.

4 Borkowska, „Opowiedzieć umieranie”, 47.

5 Inga Iwasiów, Umarł mi. Notatnik żałoby (Wołowiec: Wydawnictwo Czarne, 2013), nota z okładki.

6 Erica Jong, Fear of Dying (Nowy Jork: St. Martin’s Press, 2015), 109 [tłum. moje - M.S.]. 
jest tylko jeden prawdziwy podział, jedna rzeczywista dychotomia: życie i śmierć. Albo się żyje, albo nie. Wszystko inne jest płynne, plastyczne ${ }^{7}$

Nie dążę tutaj do monograficznego ujęcia tematu stosunku krytyczek feministycznych do ojców. Nie podejmuję również próby zrekonstruowania biografii Wacława Nałkowskiego czy - tym bardziej - Zofii Nałkowskiej. Interesuje mnie natomiast sposób, w jaki pisarka, tworząc biografię swojego ojca, zapisuje siebie w tekście. Mówiąc inaczej: jak biografia staje się autobiografią? Albo też: w jaki sposób manifestuje się autobiograficzność eseju biograficznego napisanego przez kobietę?

\section{Ojciec}

Rola, jaką odegrał Wacław Nałkowski w życiu córki, jest nie do przecenienia. To on zadbał o jej rozwój intelektualny, nie tylko zapewniając odpowiednią edukację oraz intelektualną atmosferę w domu, lecz także prowadząc rozmowy z młodą Zofią. W 1929 roku na łamach „Wiadomości Literackich” pisarka wyznawała:

Ozdobą [mojego życia] była przyjaźń z ojcem, trwająca od początku aż do jego śmierci. [...] Ojciec rozmawiał ze mną jak z kimś dorosłym, o wszystkim, o czym chciałam. Gdy coś w życiu lub książkach gniewało mnie i doprowadzało do łez, jemu robiłam o to wyrzuty. I on godził się na tę rolę, brał jakby przede mną odpowiedzialność za świat. Zdaje mi się, że nigdy nie kłamał. Nie dawał mi żadnych nieprawdziwych pedagogicznych wyjaśnień, mówił tak, jak naprawdę sądził. Nieraz namyślał się, mówiąc. A niekiedy szczerze odpowiadał, że nie wie, gdy zapytanie należało do tych, które są bez odpowiedzi ${ }^{8}$.

Co jednak interesujące, to nie ojciec, lecz matka jest kluczową postacią diariusza Nałkowskiej. Magdalena Marszałek zauważa, że we wczesnym dzienniku pisarka poświęca Wacławowi wiele miejsca, relacjonując rozmowy z nim i prezentując obraz zapracowanego intelektualisty. Po jego śmierci natomiast postać Nałkowskiego pojawia się sporadycznie. Badaczka podkreśla, że:

Milczenie Nałkowskiej o ojcu jest konsekwentne; w przeciwieństwie zaś do ojca matka, Anna Nałkowska, stanie się z czasem głównym tematem dziennika - i to właśnie w chorobie, umieraniu i po śmierci. Ojciec powraca dopiero w późnym okresie życia Nałkowskiej

7 Susan Faludi, $W$ ciemni, tłum. Joanna Bednarek (Warszawa: Wydawnictwo Krytyki Politycznej, 2017), 413.

8 Zofia Nałkowska, „O sobie”, w: taż, Widzenia bliskie i dalekie (Warszawa: Czytelnik, 1957), 12-13; (Wiadomości Literackie 47 (1929)). 
do jej dziennika, kiedy pracuje ona - ponad dziesięć lat - nad nigdy nie ukończoną w pierwotnie planowanym wymiarze biografią ojca' ${ }^{9}$.

Na marginesie warto jeszcze wspomnieć, że również postacie ojców w jej powieściach są problematyczne, o czym wzmiankuje Ewa Kraskowska: „To zdumiewające, że w książkach Nałkowskiej, która sama wzrosła w szlachetnej atmosferze rodzinnej i która tę atmosferę zawsze kultywowała, dzieci tak często wstydzą się swoich ojców i najchętniej by się ich wyparły" ${ }^{10}$.

Dlatego też pod koniec życia pisarki praca nad książką o ojcu stała się niezwykle ważna:

Głęboką radością jest dziś dla mnie czytanie ojca pism polemicznych. Rozumiem je teraz lepiej niż za jego życia. Wiem dziś, patrząc na świat otaczający, jak kosztowną rzeczą było zajęcie tamtych stanowisk, jakim życiowym luksusem było utrzymanie się na nich do końca. Ich słuszność potwierdziły przemijające lata. Jego dowcip do dziś jest celny i niezawodny. Jakąż rozkoszą musiało być dla niego tak pisać!

Odeszłam w swoją drogę. Nie umiałam bowiem sobie wyobrazić, nie umiałam sobie pomyśleć całości świata jak on. Moja przenikliwość działa na małych odcinkach, usiłuje sięgnąć w dół, nie umie sięgnąć w dal. Nie widzę dość wyraźnie jutra i wczoraj. Jestem skupiona na dziś, jestem cała zaszyta w teraźniejszości, jak w matni.

Nie umiałam uwierzyć w nieśmiertelność życia. Całą moją siłę moralną wyczerpał podziw, że ono jest.

Tak teraz sobie tłumaczę to, co mię długo bolało: że nie zaparłszy się ich, nie umiałam jednak bronić jego przekonań tak, jak pragnęłam w młodości ${ }^{11}$.

Na marginesie warto zauważyć, że poglądy Nałkowskiej dotyczące emancypacji i feminizmu w młodości kształtowały się między innymi pod wpływem ojca. W dzienniku pod datą 5 lipca 1900 pisarka odnotowuje:

Dziś przyszedł do mnie na górę ojciec, usiadł na fotelu i gadaliśmy parę godzin. Zabawnie niepodobne są nasze rozmowy do owych tradycyjnych rozmów ojców z córkami. [...] Szczególnie zgadzamy się w kwestii kobiecej. Tu ma ojciec pewne odruchowe nabyte przez ciąg wieków tradycje, ale zdolny jest wszystko pojąć i uwzględnić, jeżeli jest dowiedzione. Zresztą i w nienawiści do współczesnych feministek - schodzimy się. Nie zdarzyło mi się dotąd spotkać nigdzie właściwego objęcia kwestii kobiecej: jedne prawią o wyzwoleniu

\footnotetext{
9 Magdalena Marszałek, „Życie i papier”. Autobiograficzny projekt Zofii Nałkowskiej: „Dzienniki” 1899-1954 (Kraków: Towarzystwo Autorów i Wydawców Prac Naukowych Universitas, 2004), 102.

10 Ewa Kraskowska, „Niebezpieczne związki. Jeszcze raz o prozie Zofii Nałkowskiej”, Teksty Drugie 4 (1996): 87.

11 Nałkowska, „O Wacławie Nałkowskim”, 1.
} 
fizycznym, drugie obmyślają stowarzyszenia przeciw hulankom mężczyzny, inne obawiają się, by ich pragnienia wiedzy i ekonomicznej swobody nie wzięto za pragnienie „swobody obyczajów” [...], a wszystkie nienawidzą mężczyzn. Według ojca należy się starać przede wszystkim o ekonomiczne równouprawnienie kobiety. Ale czy to zda się na co, wobec tej zasadniczej różnicy, jaka istnieje między mężczyzną i kobietą. W jakichkolwiek warunkach ich postawić - dojdzie do takiej sytuacji, jaka panuje obecnie.

Ojciec należy do tego gatunku ludzi, którzy, zwątpiwszy o wszystkim, pozostawiają sobie jednak jednego bałwana, jako ostatni ratunek. Dla ojca jest on - kultem siły i walki jako absolutu. Do tego sprowadza ${ }^{12}$.

Wszystkie te wspomnienia stały się impulsem do napisania książki o ojcu.

\section{Książka o ojcu}

Jak ustaliła Hanna Kirchner, Nałkowska rozpoczęła pracę nad książką o ojcu około 1936 roku. Na przykład w 1937 pisarka odbyła podróż do Włodkowa, do domu dziadków Wacława, a w dzienniku pod datą 10 listopada 1938 notuje: „Najlepiej jest, gdy [...] nie mogąc spać, obmyślam tę książkę o ojcu”13. Zapisków takich pojawia się w dzienniku więcej: „Za to wspaniale idzie mi układanie materiałów do tej pracy o ojcu. Jakie dokumenty, co za listy!” (21 I 1939) albo „od dziś biorę się na nowo do życiorysu ojca, tej ślicznej, przerwanej pracy” (19 IV 1939). Efektem tego jest cykl artykułów drukowanych w prasie literackiej, z których pierwszy ukazał się w 1947 na łamach „Odrodzenia”" ${ }^{14}$ Następnie w skróconej wersji zostały one wydane w Pismach wybranych w 1954 pod wspólnym tytułem Życie wznowione. Stało się to bazą do powstania książeczki adresowanej do młodych czytelników pod tytułem Mój ojciec (1955). Z kolei na podstawie tej publikacji przygotowano do druku Życie wznowione w drugim wydaniu Pism wybranych z 1956. Wspominam o tych wszystkich wydaniach dlatego,

\footnotetext{
12 Zofia Nałkowska, Dzienniki 1899-1905 Warszawa: Czytelnik (1975), 108-110. Warto w tym miejscu dodać, że Wacław Nałkowski włączał się w dyskusje dotyczące równouprawnienia kobiet i był gorącym zwolennikiem emancypacji, o czym świadczą jego trzy artykuły: Pamiętnik uczonej kobiety, Sienkiewicziana, Nie tędy droga Szanowny Panie!. Ten ostatni stanowi polemikę z mizoginiczną książką Karola Niedziałkowskiego Nie tędy droga, Szanowne Panie! (1900).

13 Wszystkie cytaty z Dziennika Nałkowskiej z tego czasu podaję za: Hanna Kirchner, Nałkowska albo życie pisane (Warszawa: Wydawnictwo WAB, 2011), 763-764.

14 Nałkowska, „O Wacławie Nałkowskim. Rozdział pierwszy książki o ojcu”, Odrodzenie 47 (1947); „Niedobre interesy prababki Zuzanny. Rozdział książki o ojcu”, Kuźnica 13-14 (1948); „Cygan Dżęga”, Nowiny Literackie 20 (1948); „,Dzieciństwa radości i gorycze”, Kuźnica 45 (1949); „Krzysztof Kolumb. Z książki o Wacławie Nałkowskim”, Twórczość 10 (1950); „Młodość udręczona. Z książki o Wacławie Nałkowskim”, Twórczość 11 (1950); „Życie wznowione. Z materiałów do Książki o ojcu”, Myśl Współczesna 5 (1951); „Z materiałów do książki o Wacławie Nałkowskim”, Życie Literackie 22 (1952).
} 
że - w gruncie rzeczy - mamy do czynienia z czterema wersjami „książki o ojcu”, z czego sama autorka ingerowała $\mathrm{w}$ trzech pierwszych. Zmiany te są istotne, ponieważ - uprzedzając pewne fakty - powiedzieć można, że na przestrzeni dosłownie kilku lat, przy kolejnych edycjach tekstu, zaszła zmiana genologiczna: od - jak to określiła Kirchner - „utworu niewiadomego jeszcze gatunku - biografii dokumentalnej, vie romancée, monografii” 15 , do dydaktycznej hagiografii.

Niewątpliwie najciekawszą, bo i najobszerniejszą wersją są rozdziały drukowane w prasie. Charakter planowanej książki o ojcu objawia się tu w pełni. A wcale nie jest oczywisty, z czego Nałkowska doskonale zdawała sobie sprawę. Na przykład w 1942 roku w dzienniku pisała:

Jestem [...] w pracy niemal nieprzerwanej nad książką o ojcu. Może to być piękna książka, jeśli jej jakoś nie zepsuję, jeżeli oświeci mię w porę jasnowidzenie. Bo jest trudna - i żaden typ życiorysu nie może mi być wzorem. Natura tematu, natura materiału - wymaga jakiegoś własnego ujęcia, które narzuciło mi się od razu, a jest ryzykowne. Temat - to jest ten człowiek i jego rodzina, i jego życie później - już publiczne, już jawne (jeszcze trudniejsze). A dla mnie, jako temat, pociągający bardziej jest sposób poznawania, wznawiania tego życia, wydzieranie go po kawałku z tego nieistnienia, w jakie popadło. Chce mi się podawać wciąż sam materiał, nie użytkować go, ale układać go i zestawiać - wtedy nawet, gdy nie jest wartościowy. Bo jest taki żywy, tak całkowicie autentyczny. (27 VIII 1942)

Gest zestawiania, układania, sortowania staje się kluczowy dla Nałkowskiej. A jego symbolem okazuje się - wielokrotnie wzmiankowana - odnaleziona walizka z różnymi dokumentami ojca, z której „wyszły długie lata, wyszli różni ludzie” ${ }^{16}$. Kirchner podkreśla, że „magiczna «walizeczka» z dokumentami stała się dla Nałkowskiej prawdziwą laterna magica, w której obrazach zobaczyła ojca nieznanego. Uczyła się go, a czytanie «papierów» [...] było dla pisarki seansem miłości, empatii i zachwytu" ${ }^{17}$. Planowana książka o Nałkowskim zaczyna poniekąd przypominać sylwy. Jej wyjątkowość objawia się w różnorodności. Pisarka zamieszcza fragmenty listów i notatek Wacława, jego chłopięcy dzienniczek, pisma rodzinne, notatki z gazet. Symptomatyczna jest chociażby historia pewnej książki, która stała się dla Nałkowskiej prawdziwym skarbem. Chodzi o publikację pod tytułem Krzysztof Kolumb czyli odkrycie Ameryki skreślone dla ciekawej młodzi przez Hipolita Witowskiego (1853), a w niej następujący wpis:

\footnotetext{
15 Kirchner, Nałkowska, 763.

16 Nałkowska, „Niedobre interesy”, 1.

17 Kirchner, Nałkowska, 775.
} 
Nagroda ogólna 2a na posiedzeniu Zgromadzenia Nauczycielskiego przyznana Nałkowskiemu Wacławowi, uczniowi klasy I-ej Gimnazjum w Lublinie za pilność w naukach i wzorowe sprawowanie się w ciągu roku szkolnego 1864/1865. Lublin d. 18/30 czerwca $1865^{18}$.

Dla pisarki to ważne odkrycie, nie tylko dlatego, że - o czym pisze z dumą - to nagroda drugiego stopnia wśród wszystkich uczniów wszystkich klas, ale przede wszystkim z tego powodu, że książeczka ta staje się impulsem do zobaczenia ojca z tamtych lat: chorowitego, pilnego, ciekawego świata młodzieńca. Podsumowuje to tak: „Jak niezapomniane listy Reynbergów, jak weksle prababki Zuzanny Nałkowskiej, i ta książeczka w sposób całkowicie przypadkowy ocalała z Pożaru Warszawy"19.

W planowanej książce o ojcu pojawiają się obszerne fragmenty tylko pośrednio związane z Nałkowskim. Na przykład wspaniała, a zarazem zabawna historia prababki Zuzanny (matki ojca Wacława), która - na nieszczęście pisarki - handlowała okowitą z Żydami. Nałkowska pisze:

Wyszedłszy [z walizki - M.S.] ukazała się nie cała, skoro nie zostało po niej nic prócz kilku weksli, trochę kwitów i rachunków oraz mnóstwo listów pewnej zaprzyjaźnionej rodziny, która nosiła nazwisko Reinbergów. I zachowała się już na zawsze w tej cząstkowej postaci. Zwrócona jest ku nam tylko jedną stroną siebie - tak, jak ją widać z tych papierów. Nie ma wieku, nie ma rysopisu. Nie jest pewne, jaka była, dobra czy zła, brzydka czy piękna. Pewne zaś - niestety - jest tylko to, że handlowała okowitą ${ }^{20}$.

Inna historia dotyczy z kolei stryjecznego dziadka matki Wacława - Celiny z Rudnickich pułkownika Piotra Strzyżewskiego. Jeszcze inne - szkolnych lat ojca, studiów, śmierci rodziców, pierwszych przyjaźni, pierwszej miłości, „domu nad łąkami”. Pisarka wspomina również, że w wyniku wojennej zawieruchy spaliły się rękopisy Nałkowskiego oraz jego korespondencja z Żeromskim, Irzykowskim, Berentem i Szymanowskim. Ponadto zamieszcza też fragmenty będące rozważaniami filozoficznymi i społecznymi. Przytacza również wypowiedzi innych osób na temat ojca. Chociażby opis jego wyglądu odnotowany przez Helenę Boguszewską w Czekamy na życie: „Pan Nałkowski był wysoki, smukły, piękny, z ciemną chmurą włosów nad bladością twarzy pociągłej, o długim nosie, z połyskiwaniem szkieł niedostępnych binokli, z błyskiem ślicznego uśmiechu nad czarnością brody”21.

\footnotetext{
18 Nałkowska, „Krzysztof Kolumb”, 27.

19 Tamże.

20 Nałkowska, „Niedobre interesy”, 1.

21 Zofia Nałkowska, Mój ojciec (Warszawa: Nasza Księgarnia, 1955), 33.
} 
Ujawnia się tu zatem istotny rys książki o Nałkowskim. Autorka Granicy nie tylko przytacza wyimki z rozmaitych dokumentów rodzinnych, lecz także przywołuje własne wspomnienia i fragmenty dziennika. Całość powiązała więc nie tyle gestem biograficznym, ile autobiograficznym. Staje się drugą - obok Wacława - bohaterką. Odzyskuje jego życie, ale też - swoje. Tym samym „sposób poznawania, wznawiania życia” staje się również sposobem samopoznania, wznawiania własnego życia.

\section{Zakończenie}

Materiały do książki o ojcu, publikowane na łamach prasy, są interesującymi tekstami ze względu na ich przynależność gatunkową. Przede wszystkim stanowią biografię, ale też autobiografię. Ich różnorodność zbliża je do gatunków sylwicznych, a także - do eseju. Wszystkie te materiały przeszły jednak istotną przemianę, związaną z wymazywaniem pewnych fragmentów - właśnie tych dotyczących samej Nałkowskiej, w wyniku czego powstała książeczka dla młodzieży pod tytułem Mój ojciec. Autobiografia stała się biografią, co więcej - pewnego rodzaju hagiografią, jako że Wacław Nałkowski jawi się w niej jako człowiek nieskazitelny, „święty ateista”.

Życie wznowione, zapisane od nowa, powtórzone, odzyskane. Wznawianie życia to może być jedna z metafor genologicznych (auto)biograficznego eseju kobiet. Ale tylko wówczas, gdy wykonuje się gest podwójny - wznawiam cudze życie, ale zarazem wznawiam swoje. 21 stycznia 1939 roku Nałkowska notowała: „Wznawianie tego umarłego życia w całości to jest rzecz porywająca”. Porywająca dlatego, że wznawiając jego życie, wznawiała swoje życie, siebie sprzed lat. I jestem przekonany, że mówiąc o autobiograficzności eseju kobiet, nie można zapominać o tym geście „porywającego wznawiania życia”. Na tym prawie opowieść o „jej ojcu” staje się opowieścią o „jego córce”.

\section{Postscriptum}

W Dzienniku 1909-1917 pod datą 20 stycznia 1911 wiele lat później Nałkowska dopisała zdanie w nawiasie: „Śmierć ojca 29 I 1911”22. Hanna Kirchner opisuje jego śmierć w następujący sposób:

Wacław Nałkowski upadł nagle na jednej z ulic Mariensztatu, na skutek wylewu krwi do mózgu. Przewieziony do szpitala praskiego, leżał tam przez kilka dni nie odzyskując przytomności. Rodzina odnalazła go dopiero po pewnym czasie. Siostry szpitalne sprowadziły księdza, którego jednak Anna Nałkowska, stojąc na straży całościowej postawy

22 Zofia Nałkowska, Dzienniki 1909-1917 (Warszawa: Czytelnik, 1976), 180. 
ideowej męża, nie dopuściła do umierającego. Pogrzeb (31 I) był także świecki i stał się prawdziwą manifestacją „czerwonej Warszawy”. Nieznane ręce położyły na trumnie Wacława wieniec z czerni przewiązany czerwoną wstęgą, co wywołało interwencję policji carskiej. Nałkowski został pochowany na Powązkach. W 1926 na jego grobie stanął posąg „Bojownika”, wyrzeźbiony przez córkę Hannę²3.

Izabella Kaluta zauważa: „Jej ostatnim pisarskim przedsięwzięciem będzie duża książka o ojcu, zatytułowana Życie wznowione, lecz książki tej nigdy nie dokończy: pracę przerwie jej wylew krwi do mózgu - nawet jej śmierć do złudzenia przypominać będzie jego śmierć” ${ }^{24}$.

\section{Bibliografia}

Borkowska, Grażyna. „Dzienniki Zofii Nałkowskiej i Dzienniki Marii Dąbrowskiej”. W: taż. Cudzoziemki. Studia o polskiej prozie kobiecej. Warszawa: Instytut Biblioteki Literackiej-Wydawnictwo, 1996.

Borkowska, Grażyna. „Opowiedzieć umieranie”. Teksty Drugie 5 (2004).

Faludi, Susan. W ciemni. Tłum. Joanna Bednarek. Warszawa: Wydawnictwo Krytyki Politycznej, 2017.

Iwasiów, Inga. Umarł mi. Notatnik żałoby. Wołowiec: Wydawnictwo Czarne, 2013.

Jong, Erica. Fear of Dying. Nowy Jork: St. Martin’s Press, 2015.

Kaluta, Izabella. „Pisać Nałkowską”. Teksty Drugie 1-2 (1999).

Kirchner, Hanna. Nałkowska albo życie pisane. Warszawa: Wydawnictwo WAB, 2011.

Kraskowska, Ewa. „Niebezpieczne związki. Jeszcze raz o prozie Zofii Nałkowskiej”. Teksty Drugie 4 (1996).

Kraskowska, Ewa. Zofia Nałkowska. Poznań: Rebis, 1999.

Marszałek, Magdalena. „Życie i papier”. Autobiograficzny projekt Zofii Nałkowskiej: „Dzienniki” 1899-1954. Kraków: Towarzystwo Autorów i Wydawców Prac Naukowych Universitas, 2004.

Nałkowska, Zofia. „Cygan Dżęga”. Nowiny Literackie 20 (1948).

Nałkowska, Zofia. „Dzieciństwa radości i gorycze”. Kuźnica 45 (1949).

Nałkowska, Zofia. Dzienniki 1899-1905. Warszawa: Czytelnik, 1975.

Nałkowska, Zofia. Dzienniki 1909-1917. Warszawa: Czytelnik, 1976.

Nałkowska, Zofia. „Krzysztof Kolumb. Z książki o Wacławie Nałkowskim”. Twórczość 10 (1950).

\footnotetext{
23 Hanna Kirchner, „Przypis”, w: Zofia Nałkowska, Dzienniki 1909-1917, 180-181.

24 Izabella Kaluta, „Pisać Nałkowską”, Teksty Drugie 1-2 (1999): 209.
} 
Nałkowska, Zofia. „Młodość udręczona. Z książki o Wacławie Nałkowskim”. Twórczość 11 (1950). Nałkowska, Zofia. Mój ojciec. Warszawa: Nasza Księgarnia, 1955.

Nałkowska, Zofia. „Niedobre interesy prababki Zuzanny. Rozdział książki o ojcu”. Kuźnica 13-14 (1948).

Nałkowska, Zofia. „O sobie”.W: taż, Widzenia bliskie i dalekie. Warszawa: Czytelnik, 1957.

Nałkowska, Zofia. „O Wacławie Nałkowskim. Rozdział pierwszy książki o ojcu”. Odrodzenie 47 (1947).

Nałkowska, Zofia. „Z materiałów do książki o Wacławie Nałkowskim”. Życie Literackie 22 (1952).

Nałkowska, Zofia. „Życie wznowione. Z materiałów do Książki o ojcu”. Myśl Współczesna 5 (1951).

\section{Her Father. Zofia Nałkowska}

\section{Summary}

The article concerns Zofia Nałkowska's book that had been never finished and is dedicated to her father Wacław Nałkowski. It starts with the memory of his last living moments which are placed in the context of other similar memories noted by feminist writers (Nancy K. Miller, Grażyna Borkowska, Inga Iwasiów, Erica Jong and Susan Faludi). Next I mention about the relationship between Nałkowska and her father. And followingly - about the method of working on the book effected in several articles. Contents of the book about the father publicated in press are interesting texts due to text categorization. Most of all they constitute biography, but also autobiography. The textual diversity makes them closer to silva rerum and essay too.

\section{Keywords}

Zofia Nałkowska, Wacław Nałkowski, essay, autobiography, women

Translated by Mateusz Skucha 